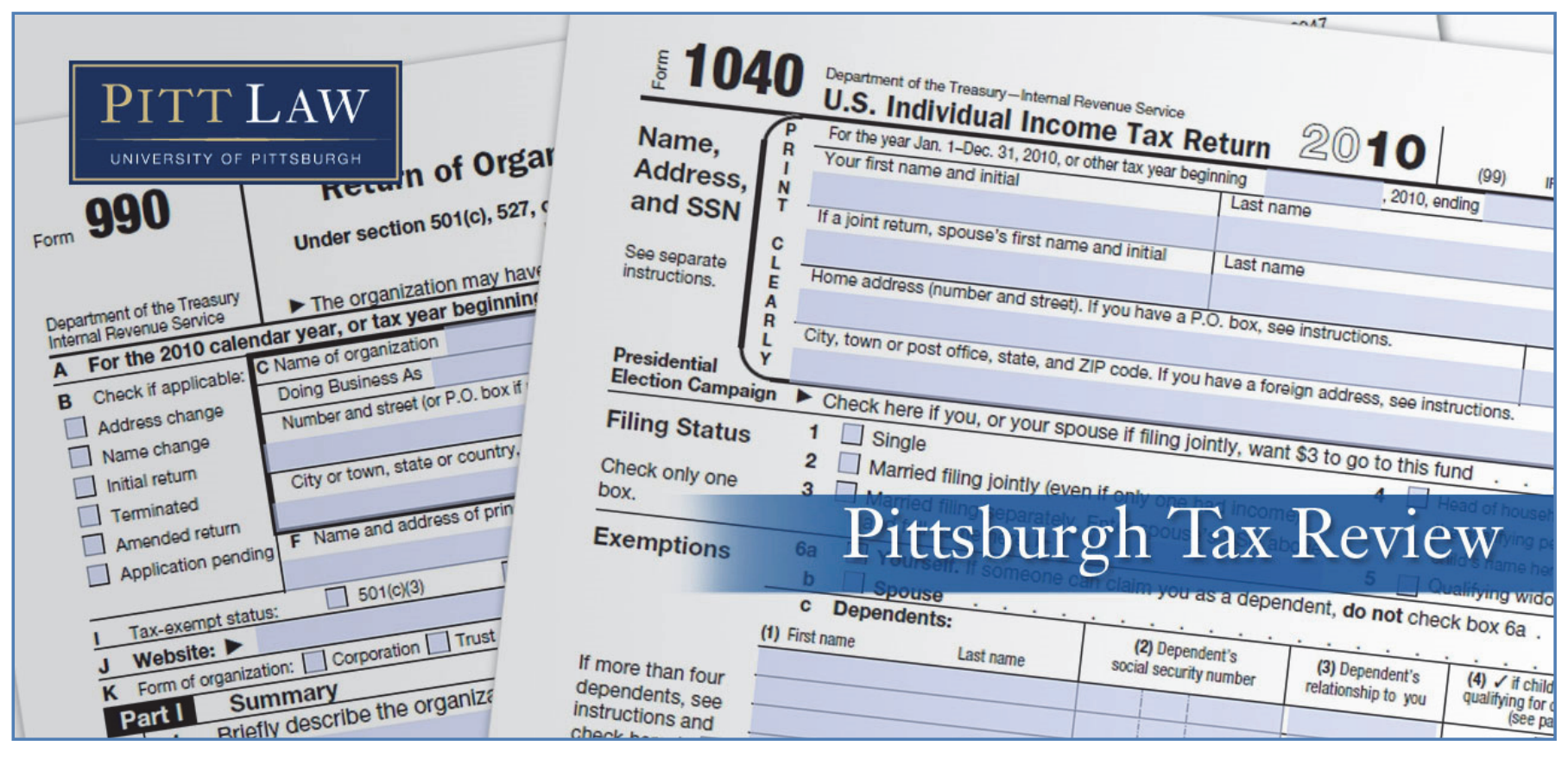

Volume 18 (2020) | ISSN 1932-1821 (print) 1932-1996 (online)

DOI 10.5195/taxreview.2020.117 | http://taxreview.law.pitt.edu

\title{
NINA OLSON: A CHAMPION FOR TAXPAYER-CENTERED TAX ADMINISTRATION
}

\section{Leslie Book}

\section{(cc) EY-NO-ND}

This work is licensed under a Creative Commons Attribution-Noncommercial-No Derivative Works 3.0 United States License.

\section{UILIS D-Sonfe}

This journal is published by the University Library System of the University of Pittsburgh as part of its D-Scribe Digital Publishing Program, and is cosponsored by the University of Pittsburgh Press. 


\title{
NINA OLSON: A CHAMPION FOR TAXPAYER-CENTERED TAX ADMINISTRATION
}

\author{
Leslie Book ${ }^{*}$
}

Meeting Nina Olson changed my life. After seeing her and the late Janet Spragens at an ABA Tax Section panel discussing tax clinics, ${ }^{1}$ I was motivated to start a new career. Eventually, I left private practice and directed a tax clinic. Now I teach and write as a law professor. I am far from the only person whose career trajectory changed after meeting and listening to Nina. Her commitment, skill, and passion have inspired many. ${ }^{2}$

\footnotetext{
* Professor of Law, Villanova University Charles Widger School of Law. Many thanks for the research assistance of Christopher J. Merken, J.D. (2020), Villanova University Charles Widger School of Law. I received helpful comments on an earlier draft from Keith Fogg and Margot Crandall-Hollick.

${ }^{1}$ I have told this story countless times and will spare another telling. See Leslie Book, Academic Clinics: Benefitting Students, Taxpayers, and the Tax System, 68 TAX LAW. 449, 449-51 (2015).

${ }^{2}$ Over the course of a few weeks in July of 2019, the blog PROCEDURALLY TAXING ran a series of tributes to Nina and most touched on how Nina's work had a direct and personal impact. See Jack Manhire, Reflections on the Impact of Nina Olson as National Taxpayer Advocate by Jack Manhire, PROCEDURALly TAXING (July 31, 2019), https://procedurallytaxing.com/reflections-on-the-impact-ofnina-olson-as-national-taxpayer-advocate-by-jack-manhire/; Armando Gomez, Reflections on the Impact of Nina Olson by Armando Gomez, PROCEDURALlY TAXING (July 31, 2019), https://procedurallytaxing .com/reflections-on-the-impact-of-nina-olson-by-armando-gomez/; Sheri Dillon, Reflections on the Impact of Nina Olson by Sheri Dillon, Procedurally TAXING (July 30, 2019), https:// procedurallytaxing.com/reflections-on-the-impact-of-nina-olson-by-sheri-dillon/; Soreé Finley, Reflection on the Impact of Nina Olson by Soreé Finley, PROCEDURALly TAXING (July 29, 2019), https:// procedurallytaxing.com/reflection-on-the-impact-of-nina-olson-by-soree-finley/; Alice Abreu, Reflections on the Impact of Nina Olson by Alice Abreu, PROCEDURALlY TAXING (July 25, 2019), https:// procedurallytaxing.com/reflections-on-the-impact-of-nina-olson-by-alice-abreu/; Bob Probasco, Reflections on the Impact of Nina Olson by Bob Probasco, Procedurally TAXING (July 24, 2019), https://procedurallytaxing.com/reflections-on-the-impact-of-nina-olson-by-bob-probasco/; David Sams, Reflections on the Impact of Nina Olson by David Sams, Procedurally TaXING (July 23, 2019), https://procedurallytaxing.com/reflections-on-the-impact-of-nina-olson-by-david-sams/; Margaret Zehren Moores, Reflections on the Impact of Nina Olson by Margaret Zehren Moores, PROCEDURALLY TAXING (July 22, 2019), https://procedurallytaxing.com/reflections-on-the-impact-of-nina-olson-bymargaret-zehren-moores/; Erin Stearns, Reflections on the Impact of Nina Olson by Erin Stearns, PROCEDURALly TAXING (July 17, 2019), https://procedurallytaxing.com/reflections-on-the-impact-ofnina-olson-by-erin-stearns/; Scott A. Schumacher, Reflections on the Impact of Nina Olson by Scott A. Schumacher, PROCEDURALlY TAXING (July 16, 2019), https://procedurallytaxing.com/reflections-onthe-impact-of-nina-olson-by-scott-a-schumacher/; Ted Afield, Reflections on Nina Olson from Ted Afield,
}

Pitt Tax Review | ISSN 1932-1821 (print) 1932-1996 (online)

DOI 10.5195/taxreview.2020.117 | http://taxreview.law.pitt.edu 
Nina is the exceptional figure whose work influenced and inspired many practitioners, while also having a systemic impact on tax administration and taxpayers in the United States and around the world. Nina's work as National Taxpayer Advocate, and before that as Director of the Community Tax Law Project, and now in "retirement" as Executive Director of the Center for Taxpayer Rights, reflects a commitment to giving voice to the oftenvoiceless taxpayers. Her commitment has led to countless administrative and legislative recommendations and numerous administrative and legislative changes reflecting those recommendations. Quite simply, her work has changed peoples' careers and improved the lives of countless taxpayers.

To truly appreciate how Nina Olson has changed tax administration, we must step back and examine the broader themes from her many reports, recommendations, and pages of testimony. In this essay, I focus on two of her works as a window into the foundational principles of Nina's thinking on tax administration. The first is her 2010 Griswold lecture where she discussed the relationship between constitutional due process and tax administration. The second is her article exploring the relationship between the IRS's EITC compliance strategy and taxpayer rights. Lest this brief essay be only thought of as reminiscing, I conclude by connecting some foundational principles in Nina's writing to a current article by Professor Jason Parkin on the state of procedural due process, an issue central to understanding the origins and likely future impact of Nina's work. ${ }^{3}$

PROCEDURALLY TAXING (July 15, 2019), https://procedurallytaxing.com/reflections-on-nina-olson-fromted-afield/; William Schmidt, Reflections on the Impact of Nina Olson by William Schmidt, PROCEDURALLY TAXING (July 12, 2019), https://procedurallytaxing.com/reflections-on-the-impact-ofnina-olson-by-william-schmidt/; Michelle Drumbl, Reflections on the Impact of Nina Olson by Michelle Drumbl, Procedurally TAXING (July 11, 2019), https://procedurallytaxing.com/reflections-on-theimpact-of-nina-olson-by-michelle-drumbl/; Rob Nassau, Reflections on the Impact of Nina Olson by Rob Nassau, Procedurally TAXING (July 10, 2019), https://procedurallytaxing.com/reflections-on-theimpact-of-nina-olson-by-rob-nassau/; Luz Arevalo, Reflections on the Impact of Nina Olson by Luz Arevalo, Procedurally TAXING (July 9, 2019), https://procedurallytaxing.com/reflections-on-theimpact-of-nina-olson-by-luz-arevalo/; T. Keith Fogg, Reflections on Nina Olson as the National Taxpayer Advocate, PROCEDURALLY TAXING (Mar. 8, 2019), https://procedurallytaxing.com/reflections-on-ninaolsen-as-the-national-taxpayer-advocate/.

${ }^{3}$ Jason Parkin, Dialogic Due Process, 167 U. PA. L. REV. 1115 (2019).

Pitt Tax Review | ISSN 1932-1821 (print) 1932-1996 (online)

DOI 10.5195/taxreview.2020.117 | http://taxreview.law.pitt.edu 


\section{THE 2010 GRISWOLD LECTURE: DUE PROCESS AND “OH YeAH? WHO SAYS?"}

\section{A. The General Themes: A Focus on Process}

Nina's philosophy on tax administration was clearly expressed in the 2010 Erwin N. Griswold Lecture Nina delivered before the American College of Tax Counsel in San Antonio, Texas. ${ }^{4}$ Her lecture began by noting that from her modest beginnings as an uncredentialed return preparer through her time as National Taxpayer Advocate, she has "strived to hold the Service accountable to its taxpayers." That striving had led to the subject of the lecture: procedural due process and its impact on the tax system.

Nina admitted to "always having trouble with the concepts of sovereign and sovereign authority - when someone says you must do this, my first reaction - for reasons that go back to the recesses of my early childhood-is to say, Oh yeah? Who says?"6

While this article was not the first time Nina thought, or even wrote about, due process, ${ }^{7}$ she took the occasion to consider its "historical and philosophical bases." ${ }^{\prime 8}$ In the lecture, Nina discussed the historical roots of due process to the Magna Carta and how it reflected a need to protect individuals from at times an overreaching and erroneous sovereign:

$[T]$ he very words used in Supreme Court due process analysis raise images of an all-powerful sovereign that can abuse and oppress the people. To protect against this abuse, we have come to believe that when the sovereign acts upon life, liberty, and property interests, the persons who are impacted must have some

\footnotetext{
${ }^{4}$ The speech was subsequently published. Nina Olson, Taking the Bull by Its Horns: Some Thoughts on Constitutional Due Process in Tax Collection, 63 TAX LAW. 227 (2010).

${ }^{5}$ Id. at 227.

${ }^{6} I d$. at 228 .

${ }^{7}$ Leslie Book, Taxpayer Rights: A Look Back to Congressional Testimony of Michael Saltzman and Nina Olson, FORBES (Feb. 23, 2015), https://www.forbes.com/sites/procedurallytaxing/2015/02/23/ taxpayer-rights-a-look-back-to-congressional-testimony-of-michael-saltzman-and-ninaolson/\#2bc50a536ed7 (discussing 1997 testimony addressing due process concepts).

${ }^{8}$ Olson, supra note 4 , at 228.
}

Pitt Tax Review | ISSN 1932-1821 (print) 1932-1996 (online) DOI 10.5195/taxreview.2020.117 | http://taxreview.law.pitt.edu 


\section{4 | Pittsburgh Tax Review |Vol. 182020}

individualized method of protesting that action, even though the law is addressed to the populace as a whole. That is, we have to think about the individual as well. ${ }^{9}$

What does thinking about the individual mean in the context of due process? As Nina explained in her speech, procedural due process typically requires the sovereign provide notice of its actions and an opportunity for individuals to be heard when its actions have an impact on a protected interest like life, liberty, or property. In addition, Nina extended the benefits of due process beyond a focus on any one person's interest in a given matter. She asked us to take a step back and consider the larger implications at play when we consider how the sovereign relates to its citizens:

The value of procedural due process goes beyond protecting an individual's interests, as important as that is. Procedural due process raises the question of what it means to be constituted as a government. It provides the individual with the ability to interact with the government, to be treated as a person and with dignity. ${ }^{10}$

Rather than just focus on outcomes, Nina explained that due process highlights broader issues of how the government interacts with its citizens:

It requires that there be a conversation about what is being done to that person and why it is being done. Even when the outcome of the dialogue is clear-indeed, especially when the outcome will be unchanged - the right to be heard, that is, to explain to the sovereign how its action will affect you, and the right to have that government action explained to you, make individuals feel that their government is acknowledging their individual circumstances and importance even as it acts for the benefit of the whole. Procedural due process, then, is an aspect of procedural justice, which many commentators believe is a necessary component for individuals to come together and voluntarily consent to be governed. ${ }^{11}$

\section{B. Bringing it to Tax}

After generally providing context for why due process is rightly situated as a tool to encourage the sovereign to listen to citizens, Nina took the logical next step, which is to call for tax administrators to emphasize ways to ensure they provide "meaningful" opportunities for citizens to be heard. The call to action raised some key questions. What is meaningful in the context of tax

\footnotetext{
${ }^{9} I d$. (emphasis added).

${ }^{10} I d$. at 229.

${ }^{11} \mathrm{Id}$.
}

Pitt Tax Review | ISSN 1932-1821 (print) 1932-1996 (online) DOI 10.5195/taxreview.2020.117 | http://taxreview.law.pitt.edu 
administration, and how has due process jurisprudence influenced that debate $?^{12}$

To help answer these questions, Nina presented a brief history and showed that "for much of the Service's existence" it has "escaped close due process analysis." 13 Why has tax been exceptional when it comes to due process? Nina summed it up succinctly, and the short answer came from the case that gave the speech its title, Bull v. United States. ${ }^{14}$ In Bull, the Supreme Court explained:

$[\mathrm{T}]$ axes are the lifeblood of government, and their prompt and certain availability an imperious need. Time out of mind, therefore, the sovereign has resorted to more drastic means of collection. The assessment is given the force of a judgment, and if the amount assessed is not paid when due, administrative officials may seize the debtor's property to satisfy the debt. ${ }^{15}$

Nina's article provided "a whirlwind tour" of procedural due process case law, looking at old chestnuts like Springer v. United States, ${ }^{16}$ Phillips $v$. Commissioner of Internal Revenue, ${ }^{17}$ and Bob Jones University v. Simon, ${ }^{18}$ which all support the idea that any procedural protections taxpayers enjoy are rooted in legislation rather than the Constitution. In these cases, the Supreme Court emphasized the prompt payment of taxes is paramount. The government's interest is so important that the courts have given tax

${ }^{12}$ Rodney L. Mott, Due Process of LAw 208 (1926) (noting "notice and hearing as a part of due process of law was a natural corollary of the idea that that phrase embodied the essential principles of the common law of England").

${ }^{13}$ Olson, supra note 4, at 230. Whether the IRS's administration of refundable credits should trigger due process concerns associated with other non-tax-based transfer programs has largely escaped careful scrutiny. For one exception, see Megan Newman, Comment, The Low-Income Tax Gap: The Hybrid Nature of the Earned Income Tax Credit Leads to Its Exclusion from Due Process Protection, 64 TAX LAW. 719 (2011).

${ }^{14}$ Bull v. United States, 295 U.S. 247 (1935).

${ }^{15}$ Id. at $259-60$.

${ }^{16}$ Springer v. United States, 102 U.S. 586, 594 (1881) ("The prompt payment of taxes is always important to the public welfare. It may be vital to the existence of a government. The idea that every taxpayer is entitled to the delays of litigation is unreason.").

${ }^{17}$ Philips v. Comm'r, 283 U.S. 589 (1931).

${ }^{18}$ Bob Jones Univ. v. Simon, 416 U.S. 725 (1974).

Pitt Tax Review | ISSN 1932-1821 (print) 1932-1996 (online) DOI 10.5195/taxreview.2020.117 | http://taxreview.law.pitt.edu 
administrators a wide berth relative to other areas where the sovereign engages with the public.

Her historical tour also included revolutionary cases like Goldberg v. Kelly where the Supreme Court held the government must provide notice and hearing before depriving welfare recipients of benefits. ${ }^{19}$ Following Goldberg, in Mathews v. Eldridge, the Supreme Court evaluated the sufficiency of procedural protections looking at a cost-benefit analysis that examined the benefit of any additional procedural protection in light of its costs. ${ }^{20}$ For the most part, cases like Goldberg and Mathews have had little impact on the tax system. In finding that tax procedures are constitutionally sound, courts tend to reflexively cite Bull, Springer and the like as justification for the status quo, so long as the taxpayer can eventually get a court to review the Service's assessment. ${ }^{21}$ In essence, due process has had little direct impact on procedural protections for taxpayers, and tax has historically sat outside some of the main procedural due process

19 See Goldberg v. Kelly, 397 U.S. 254 (1970); Jerry L. Mashaw, Due Process in the Administrative State 33 (1985) (referring to Goldberg as the place where most believe the origin of the due process revolution began). For an excellent discussion of the procedural due process in the context of welfare rights, as well as the separate rights that low[-]income taxpayers more generally enjoy by virtue of many transfer programs being embedded in the Internal Revenue Code, see Susannah Camic Tahk, The New Welfare Rights, 83 BROOK. L. REV. 875, 881-90 (2018).

${ }^{20}$ Under Mathews, courts must consider the following when determining the "specific dictates" of procedural due process:

[f]irst, the private interest that will be affected by the official action; second, the risk of an erroneous deprivation of such interest through the procedures used, and the probable value, if any, of additional or substitute procedural safeguards; and finally the Government's interest, including the function involved and the fiscal and administrative burdens that the additional or substitute procedural requirement would entail.

Mathews v. Eldridge, 424 U.S. 319, 335 (1976).

${ }^{21}$ For purposes of this essay I focus more on the hearing right associated with due process as compared to the right to notice. The Supreme Court uses a balancing test similar to that in Mathews in evaluating the adequacy of notice. See Parkin, supra note 3, at 1119; see also Mullane v. Central Hanover Bank \& Trust Co., 339 U.S. 306 (1950). It is beyond the scope of this essay to examine whether IRS correspondence in certain circumstances may in fact trigger constitutional concerns due to the correspondence inadequately notifying taxpayers of the IRS's actions. Courts have rightly emphasized that not all communication from the IRS, even if arguably deficient, should trigger constitutional concerns. See Redfern v. United States, No. 19-12649, 2019 WL 6879170, at *3 n.1 (11th Cir. 2019) (per curiam) (rejecting a due process challenge to adequacy of notice arising from IRS summons power). Other notices, especially, for example, notices that unclearly describe why the IRS is subjecting a claimed refundable credit to summary assessment procedures, should attract greater constitutional scrutiny.

Pitt Tax Review | ISSN 1932-1821 (print) 1932-1996 (online)

DOI 10.5195/taxreview.2020.117 | http://taxreview.law.pitt.edu 
developments that characterized the twentieth century due process revolution. ${ }^{22}$

In acknowledging that courts view tax exceptionally when thinking about due process, Nina asked where this leaves taxpayers:

So, where are we? The courts seem to be saying that because from "time out of mind" the sovereign's power to require payment of taxes immediately to satisfy the government need is almost as "old as the common law," the government's summary collection procedures pass constitutional muster so long as the taxpayer is afforded an eventual and ultimate avenue of judicial review. ${ }^{23}$

\section{Taking the "Bull" by Its Horns}

The absence of constitutional protections has not meant taxpayers have not indirectly benefitted from the concerns underlying constitutional protections. Through pre-assessment judicial review in deficiency procedures, to pre-revocation judicial review for tax-exempt entities, to additional notice and post-assessment judicial review in cases involving jeopardy, and the collection due process notice and hearing rights, Congress has provided protections to taxpayers directly reflective of the understanding that the sovereign makes mistakes, individuals' interests are important, and process matters.

While the courts have been, and are still, $^{24}$ reluctant to find a constitutional mandate for things we now mostly take for granted in the

${ }^{22}$ See Leslie Book, The Collection Due Process Rights: A Misstep or a Step in the Right Direction?, 41 Hous. L. REv. 1145, 1175-88 (2004) (discussing tax system's somewhat uneasy relationship with procedural due process norms).

${ }^{23}$ Olson, supra note 4, at 233 (quoting Bull v. United States, 295 U.S. 247, 259 (1935)) (quoting Springer v. United States, 102 U.S. 586, 594 (1881)).

${ }^{24}$ The absence of a strong constitutional norm for the opportunity to enjoy pre-assessment judicial review still has a strong impact. See Larson v. United States, 888 F.3d 578, 586-87 (2d Cir. 2018) (citing to and discussing absence of a constitutional requirement for a pre-assessment judicial review and finding no procedural due process violation for civil penalty requiring payment of millions of dollars to generate judicial review of IRS penalty determination). In finding the absence of pre-assessment judicial review did not violate procedural due process, the United States Court of Appeals for the Second Circuit explained it was up to Congress, not the courts to address the problem, and in tax cases the "governmental interest here is singularly significant due to the careful structuring of the tax system and the Government's "substantial interest in protecting the public purse." Id. For a discussion of Larson, as well as the Second Circuit's approach to the due process arguments that Larson raised, see T. Keith Fogg, Access to Judicial Review in Nondeficiency Tax Cases, 73 TAX Law. 435 (2020); see also Kahn v. United States, 753 F.2d

Pitt Tax Review | ISSN 1932-1821 (print) 1932-1996 (online) DOI 10.5195/taxreview.2020.117 | http://taxreview.law.pitt.edu 


\section{8 |Pittsburgh Tax Review | Vol. 182020}

modern tax system, Nina argued congressionally legislated protections reflect a positive step for tax administration. Even if advocates cannot generally use the Constitution as leverage to challenge the way the IRS assesses or collects tax, she emphasized that wise tax administrators should strive to provide meaningful opportunities for taxpayers to be heard within the existing framework:

While a due process analysis of tax administration may not implicate constitutional violations, our analysis should not stop there. As my mother used to say, "Just because you can, doesn't mean you should." 25

Because due process, as part of procedural justice, serves the larger purpose of engaging individuals and making them feel heard in a meaningful way, regardless of the outcome, it helps ease the sense among many taxpayers that the government acts in arbitrary ways. Confidence in fairness, accuracy, and consistency of government, in turn, makes taxpayers more willing to participate in government.

In her Griswold speech, Nina's emphasis on the sovereign's relationship to individuals opened the door for advocates, Congress, courts, and the IRS to focus on the impact that the IRS has on taxpayers' lives. Unlike in the times of kings (where the due process principles allowing the sovereign wide latitude in tax collection originate), governments depend on people's consent to be governed. Nina suggested it was time to turn Bull "on its head for a bit: if taxes are the lifeblood of government, then it is the taxpayers who provide that life-blood." 26

1208, 1218 (3d Cir. 1985) ("In the tax context, the constitutionality of a scheme providing for only postassessment judicial review is well-settled.").

${ }^{25}$ Olson, supra note 4, at 233. But see id. at 233 n.24. Nina does note she remains "unconvinced that there is no constitutionally protected interest in a pre-deprivation hearing in tax administration today, given that increasing automation heightens the risk that the government will make an erroneous determination and in light of the expansion of the tax filing population since Bull v. United States, or even Bob Jones University v. Simon, to include very low-income taxpayers who do not have the means to challenge government." Id.

${ }^{26}$ Olson, supra note 4, at 234.

Pitt Tax Review | ISSN 1932-1821 (print) 1932-1996 (online) DOI 10.5195/taxreview.2020.117 | http://taxreview.law.pitt.edu 


\section{PROCEDURAL JUSTICE FOR ALL: IRS AND ITS EITC COMPLIANCE STRATEGY}

\section{A. Procedural Justice and its Relation to Due Process}

After exploring due process in the Griswold lecture, Nina's article Procedural Justice for All: A Taxpayer Rights Analysis of IRS Earned Income Credit Compliance Strategy, written for the first International Taxpayer Rights conference, explored how procedural justice and taxpayer rights could help turn Bull on its head. ${ }^{27}$ Her article used the earned income tax credit (EITC) as a case study to explore how the IRS's administration of the EITC fares when looked at through the prism of procedural justice.

Before addressing the main points of her article, I return briefly to the Griswold lecture. In the Griswold speech, Nina discussed how procedural due process is "an aspect of procedural justice." ${ }^{28}$ In looking at procedural due process in the Griswold lecture, Nina was looking for a path to improve procedures that failed to adequately reflect the taxpayer's interests. As she stated, it is not enough when arguing with the sovereign to "simply" say something is not "fair" or "equitable." ${ }^{29}$ But since due process itself did not provide Nina with sufficient ammunition to change unfair or inequitable procedures, Nina looked elsewhere. That led to a different but related path that she explored in Procedural Justice for All.

In Procedural Justice for All, Nina discussed the work of Tom Tyler and other procedural justice theorists. ${ }^{30}$ As she explained, procedural justice theorists like Tyler emphasize procedural justice's foundation is based on fair decision-making and fair interpersonal treatment. Fair decision-making revolves around themes like consistency and transparency, and fair treatment

\footnotetext{
${ }^{27}$ Nina E. Olson, Procedural Justice for All: A Taxpayer Rights Analysis of IRS Earned Income Credit Compliance Strategy, in 22 ADVANCES IN TAX'N 1 (John Hasseldine ed., 2015), https://pdfs .semanticscholar.org/277b/37cf1becd0737d2a2bea29a7d5cc4ae76fdf.pdf.

${ }^{28}$ Olson, supra note 4, at 229.

${ }^{29} I d$.

${ }^{30}$ Tom R. TYLER, Why People OBey the LAW (1990) (contrasting instrumental and normative theories on why people comply with the law and emphasizing that importance of individuals' perception of the legitimacy of procedures).
}

Pitt Tax Review | ISSN 1932-1821 (print) 1932-1996 (online) DOI 10.5195/taxreview.2020.117 | http://taxreview.law.pitt.edu 
is grounded in respect and dignity, considered both at the institutional level and in specific actions. ${ }^{31}$ Nina reminded us procedural justice requires a concern for more than a just outcome; fair process is key. The inquiry is summed up by one overarching question: "Do you believe you are treated fairly in your interactions with the authority?"32 Before she used this question to explore how the IRS measures up in its EITC administration, Nina reminded us that in the United States, procedural justice norms are often most associated with the procedural due process jurisprudence she explored in her Griswold lecture. In this article, she took us back to Bull and its progeny, and again reminded readers that while the Constitution may not be the source of most of taxpayers' procedural protections, Congress has crafted legislative protections that reflect constitutional due process norms. The drumbeat of legislative protections, from the early twentieth century creation of preassessment judicial review to the 1998 IRS Restructuring and Reform Act and beyond, reflects an increasing acceptance of taxpayers themselves as a co-equal lifeblood of government.

\section{B. Procedural Justice and the EITC}

When Nina wrote her article on procedural justice and the EITC, the IRS had just administratively adopted a Taxpayer Bill of Rights (TBOR) and Congress had not yet codified TBOR. ${ }^{33}$ For years, Nina recommended both the IRS adoption and the congressional codification of those rights. ${ }^{34} \mathrm{I}$ suspect Nina would have been a forceful advocate for TBOR even if the history she discussed in her Griswold lecture were different. Yet understanding Nina and her commitment to finding a hook to challenge the status quo provides a direct line to the adoption of TBOR. As she reminded

${ }^{31}$ Olson, supra note 27 , at 4.

${ }^{32} I d$.

${ }^{33}$ See Alice G. Abreu, Temple Law Review Symposium Taxpayer Rights: All the Angles Foreword, 91 TEMP. L. REV. 679, 679 (2019) ("The TBOR is a compilation of ten taxpayer rights that are now part of the text of the Internal Revenue Code (the Code) itself and that were adopted by the IRS even before they were made a part of the Code.").

${ }^{34}$ Nina E. Olson, Toward a More Perfect Tax System: A TAXPayer Bill of RightS as a

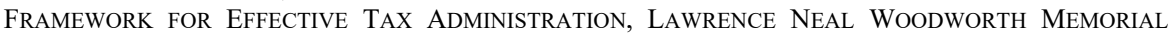
LECTURE (May 9, 2013), https://www.taxpayeradvocate.irs.gov/wp-content/uploads/2020/08/TOWARD -A-MORE-PERFECT-TAX-SYSTEM.pdf (overview of recommendations Nina made in the years before the IRS adopted the TBOR).

Pitt Tax Review | ISSN 1932-1821 (print) 1932-1996 (online) DOI 10.5195/taxreview.2020.117 | http://taxreview.law.pitt.edu 
us in her Griswold lecture, change does not come just because you assert something is unfair. ${ }^{35}$ Because procedural due process jurisprudence could not give Nina the leverage to change what she thought were unfair procedures, she looked elsewhere. Her search led her to Tyler and taxpayer rights charters ${ }^{36}$ which in her view, if the IRS adopted and Congress codified would bring "tax administration in line with other areas of administrative and constitutional law." 37

With that context, Nina explored how in so many ways the IRS's administration of the EITC falls short when looking at it from a procedural justice benchmark. ${ }^{38}$ The article reflected Nina's longstanding concern over the IRS's use of automated procedures when interacting with low-income taxpayers claiming the EITC. ${ }^{39}$ She started with the common-sense

${ }^{35}$ Olson, supra note 4, at 229.

${ }^{36}$ See Duncan Bentley, TAXPayer Rights: Theory, Origin, AND IMPLEMENTATION (2007) (discussing taxpayer rights in an international context).

${ }^{37}$ Olson, supra note 27 , at 6 .

${ }^{38}$ For readers interested in Nina's decades-long study of the earned income tax credit, see 3 NAT'L TAXPAYER ADVOCATE, OBJECTIVES REPORT TO CONGRESS: EARNED INCOME TAX CREDIT (2020). In the preface to this report (which I was lead author during a brief stint as Professor in Residence at the IRS), Nina explained she "spent much of the last 18 years thinking about how to improve the administration of the EITC. How should the IRS change its approach and processes? How should the IRS and others increase the participation rate? And how can the IRS minimize noncompliance while respecting taxpayer rights and not deterring participation by eligible taxpayers? I have attempted to seek answers and make recommendations with respect to these questions." $I d$. at vii. The report includes an extensive appendix detailing the considerable written work on the EITC that TAS produced from 2001-2019. Id. at app. 4.

${ }^{39}$ Nina explores some of these themes elsewhere. See, e.g., Nina E. Olson, A Brave New World: The Taxpayer Experience in a Post-Sequester IRS, 139 TAX NOTES 1189, 1189-90 (2013).

I believe that unless we act to change the trend, the IRS of tomorrow will have very little personal interaction with taxpayers, will be unable to adequately address the needs of a very diverse taxpayer population, and will not understand the various communities of taxpayers-geographic, economic, trade or business, cultural. It will relentlessly drive forward on the path of more automation, particularly in those very areas that require personal interaction to be effective, using automation mostly to make its own work more convenient and rarely more helpful or tailored to the taxpayer. As it does so, the IRS becomes ever more distant from understanding the needs and attitudes of the diverse taxpayer base that it is supposed to serve....

At their core, taxpayer rights are human rights. They are about our inherent humanity. Particularly when an organization is large, as is the IRS, and has power, as does the IRS, these rights serve as a bulwark against the organization's tendency to arrange things in ways

Pitt Tax Review | ISSN 1932-1821 (print) 1932-1996 (online)

DOI 10.5195/taxreview.2020.117 | http://taxreview.law.pitt.edu 
proposition that to successfully administer a program like the EITC the IRS needs to understand the characteristics of the taxpayers who claim it. In the article, she contrasted low-income taxpayer characteristics as compared to the average taxpayer's characteristics, looking at issues like literacy, language barriers, lack of access to banks and transportation, and childcare. ${ }^{40}$ She noted a correspondence-based examination program, when intertwined with the characteristics of EITC-claiming taxpayers, presents major problems for an "enforcement-oriented IRS." 11 The correspondence-based examination process creates "difficulties for taxpayers navigating the agency to claim and receive the correct amount of EITC, raising questions of procedural justice." ${ }^{42}$

In support of her claim, Nina discussed a number of TAS-based EITC research studies showing major problems taxpayers experience when interacting with EITC compliance correspondence. In this brief essay I do not summarize all of these studies, but they present evidence of taxpayers struggling to navigate these procedures. For example, the studies show many taxpayers who are denied the EITC during audit are denied often due to an inability to provide what the IRS is asking for rather than their ineligibility. ${ }^{43}$ In addition, a TAS research study showed over one-quarter of all taxpayers subject to an EITC audit did not understand the IRS was auditing their return, and only about one-half felt they understood what the IRS wanted in response to the audit letter. ${ }^{44}$

The studies Nina discussed give a different context for the IRS's challenges in administering the EITC. While Nina acknowledged that improper payments, a longstanding concern with the IRS's administration of

that are convenient for itself, but actually dehumanize us. Taxpayer rights, then, help ensure that taxpayers are treated in a humane manner.

Id.

${ }^{40}$ Olson, supra note 27 , at $9,10$.

${ }^{41} I d$. at 14 .

${ }^{42} I d$.

${ }^{43}$ Id. at 17-19 (discussing 2004 EITC Audit Recon study); see also id. at 23-24 (discussing 2012 TAS study of Tax Court EITC cases).

${ }^{44}$ Id. at 19 (citing 2 NAT'L TAXPAYER AdVOCATE, 2007 ANNUAL REPORT TO CONGRESS: IRS EARNED INCOME CREDIT AUdiTs-A CHALLENGE TO TAXPAYERS, at 94-116 (2007)).

Pitt Tax Review | ISSN 1932-1821 (print) 1932-1996 (online) DOI 10.5195/taxreview.2020.117 | $\underline{\text { http://taxreview.law.pitt.edu }}$ 
the EITC, are a legitimate concern, she questioned the IRS's traditional enforcement dominant approach:

The enforcement-dominant approach to tax administration is based on the assumptions underlying the rational actor/economic deterrence model, which describes a taxpayer's compliance behavior in terms of risk of detection and level of penalties. One problem with this model is that it encourages tax agency employees to view taxpayers as natural cheaters and to believe that the only way to keep those taxpayers in line is to undertake enforcement action. ${ }^{45}$

Nina's takeaway is that disproportionately relying on traditional enforcement tools is counterproductive. To move the needle on improper payments, the IRS must truly engage with taxpayers and understand what drives noncompliance. ${ }^{46}$ At the heart of successful tax administration is voluntary compliance, which as a necessary condition requires the IRS to take actions that enhance rather than detract from its legitimacy. Citing Tyler, Nina noted that a system that is predicated on voluntary compliance requires more than just a focus on requiring taxpayers to comply just because "they were told to do so." $" 47$

Instead, agencies should focus on a system encouraging legitimacy, including ways that a tax administrator can facilitate taxpayer trust in addition to actions premised on a traditional sanctions-based enforcement model. ${ }^{48}$ When looking at the EITC, Nina described an IRS compliance model rooted in enforcement that minimizes making voluntary compliance easier. She made practical suggestions to enhance the IRS's legitimacy with EITC-claiming taxpayers, like ensuring greater oversight over unlicensed return preparers, staffing dedicated EITC helplines, and training IRS employees to ensure a broader mindset reflective of better social and

${ }^{45}$ Olson, supra note 27, at 29.

${ }^{46}$ See Leslie Book et al., Insights from Behavioral Economics Can Improve Administration of the EITC, 37 VA. TAX REV. 177 (2018) (discussing views on EITC compliance).

${ }^{47}$ Olson, supra note 27 , at 28.

${ }^{48}$ This insight derives in part from work of Erich Kirchler, who has collaborated with Nina on research both during and after her tenure at TAS. For the Kirchler view on tax compliance, see https:// www.ncbi.nlm.nih.gov/pmc/articles/PMC4381354/. For collaborative work with Kirchler following her stint as NTA, see https://papers.ssrn.com/sol3/papers.cfm?abstract_id=3692370. For work with Kirchler while at TAS see https://taxpayeradvocate.irs.gov/Media/Default/Documents/2017-ARC/ARC17_ Volume2_05_AuditsIDtp.pdf.

Pitt Tax Review | ISSN 1932-1821 (print) 1932-1996 (online) DOI 10.5195/taxreview.2020.117 | http://taxreview.law.pitt.edu 


\section{4 | Pittsburgh Tax Review | Vol. 182020}

communication skills. ${ }^{49}$ Underlying it all, Nina notes a key theme for her recommendations: "Central to all of [the recommendations] is the requirement that the IRS attempt to understand the EITC taxpayer population's needs and how they feel about the agency when their needs are not met." ${ }^{50}$ In concluding the article, Nina offered advice for how the IRS could better understand taxpayers. Her advice came in a series of questions meant to ensure the IRS strives to understand taxpayers:

For example, how does a low-income taxpayer feel when the IRS audits him but not the preparer whom the taxpayer paid to prepare the return?

Would the taxpayer feel more open toward the agency if that agency held the preparer accountable for his own errors, and did not penalize the taxpayer for someone else's negligence or error?

What if the government didn't assess additional tax but just sent the taxpayer a letter advising that it had noticed an error on the return, noticed the taxpayer used a preparer, explained (in plain language) the source of the error, and suggested the taxpayer be extra careful with next year's return?

Would the taxpayer voluntarily correct the error the following year?

Would the taxpayer change preparers, or keep with the same one, and persist in the error?

Would the taxpayer think the IRS was a toothless tiger because no assessment was made, just a gentle tap ${ }^{51}$

\section{CONCLUSION: FUTURE IMPACT}

Nina's prolific writing will continue to occupy a prominent place among those interested in tax administration. ${ }^{52}$ This essay is meant in part to highlight some of the constitutional and theoretical foundations of Nina's work. A taxpayer-centric model of tax administration is a significant part of

${ }^{49} I d$. at 30.

${ }^{50} \mathrm{Id}$.

${ }^{51}$ Olson, supra note 27 , at 30-31.

52 The recent Temple Law School symposium concerning the impact of TBOR on tax administration is illustrative. See generally Richard K. Greenstein, Rights, Remedies, and Justice: The Paradox of Taxpayer Rights, 91 TEMP. L. REv. 743 (2019); T. Keith Fogg, Can the Taxpayer Bill of Rights Assist Your Clients?, 91 TeMP. L. Rev. 705 (2019); Leslie Book, Giving Taxpayer Rights a Seat at the Table, 91 Temp. L. REv. 759 (2019); Michelle Lyon Drumbl, Tax Attorneys as Defenders of Taxpayer Rights, 91 TEMP. L. REV. 813 (2019).

Pitt Tax Review | ISSN 1932-1821 (print) 1932-1996 (online) DOI 10.5195/taxreview.2020.117 | http://taxreview.law.pitt.edu 
Nina's legacy and finds its origins in procedural due process and procedural justice.

It is my hope that this essay is not solely, or even principally, one that just has significance for a backwards-looking perspective on the broader context of Nina's work. The concerns Nina raised as NTA are forwardlooking and should continue to drive tax administration.

In writing this essay, I thought of Professor Jason Parkin's important recent article addressing the future of procedural due process, Dialogic Due Process. ${ }^{53}$ In the article, Professor Parkin explained that after the due process revolution of the early 1970s (which as I summarized above mostly skipped the tax world) there was a retrenchment. ${ }^{54}$ Driven by the Supreme Court in Mathews v. Eldridge $e^{55}$ and the Court's adoption of a cost-benefit approach to determine procedural adequacy of notice and hearing in any context, procedural due process jurisprudence has, in, Parkin's view, largely stabilized. ${ }^{56}$ Due in part to the heavy evidentiary burden needed to justify change, courts are rarely driving procedural reforms based on procedural due process considerations. ${ }^{57}$

To Parkin, that does not mean due process no longer drives innovation. In his article, Parkin looks outside the Supreme Court to find sources of procedural innovation that reflect the due process concerns of the Supreme Court cases of the early 1970s:

Yet procedural innovation has not stopped. In recent years, federal, state, and local agencies and court systems have been experimenting with new and additional procedures in a wide range of legal contexts. Cities have passed legislation guaranteeing government-funded lawyers for indigent people facing eviction and deportation. Agencies have adopted electronic notification systems to ensure that families receiving essential public benefits are given fast and reliable notice of benefit terminations or changes. And judges have developed practices and

${ }^{53}$ See generally Parkin, supra note 3.

${ }^{54} I d$. at $1156-58$.

${ }^{55}$ Matthews, 424 U.S. at 347-48.

${ }^{56}$ Parkin, supra note 3, at 1116-17.

${ }^{57} \mathrm{Id}$. at 1117 . This in part can be explained by the significant evidentiary hurdles needed to show the value of additional procedural protections relative to increased costs associated with additional procedures. See id. at 1116-17.

Pitt Tax Review | ISSN 1932-1821 (print) 1932-1996 (online) DOI 10.5195/taxreview.2020.117 | http://taxreview.law.pitt.edu 
procedures for taking a more active role in cases involving pro se litigants. These experimental procedures hold the potential to benefit countless individuals and families, improving the fairness of legal proceedings where the stakes could not be higher. ${ }^{58}$

Parkin noted that innovation is producing new evidence of the additional value associated with procedural protections in areas that include a more robust role for judges in assisting pro se litigants and increased agency use of alternative means to notify persons that may be adversely affected by the proposed actions of government agencies. ${ }^{59}$ Because procedural due process is meant to reflect context, Parkin believes these innovations can provide useful evidence of the benefit of additional protections and may help energize new due process challenges. ${ }^{60}$

While Parkin does not discuss taxes or Nina's work, Parkin's insight has significance for those reflecting on Nina's legacy. Nina offers a compelling case to re-evaluate the reflexive dismissal of procedural due process concerns in tax just because the old cases say tax is special. ${ }^{61}$ Her focus on researchdriven studies shows the value of exploring different ways for the IRS to interact with low-income taxpayers, including for example how communicating using educational letters with individuals suspected of erroneously claiming refundable credits has an impact on likely future voluntary compliance. Her work shows that the government interest actually coincides with a taxpayer-centered focus on tax administration.

While it is typically insufficient in tax administration to drive change with the observation that something is unfair, Nina has elevated fairness with broader principles of tax administration. Her creativity and effectiveness in getting administrative and legislative acceptance of TBOR provides a

\footnotetext{
${ }^{58}$ Parkin, supra note 3, at 1118 (footnotes omitted).

${ }^{59} \mathrm{Id}$.

${ }^{60} \mathrm{Id}$. at 1119 (" $[\mathrm{P}]$ rocedural due process analysis is sensitive to the facts and circumstances of a particular procedural regime. This distinguishes due process from other individual rights conferred by the Constitution, making due process amenable to reevaluation and revision.").

${ }^{61}$ See Nina E. Olson, The IRS Might Recover EITC Using Its Newly Discovered Post-Processing Math Error Authority, but Is It Constitutional?, TAXPAYER ADVOC. SERV.: NAT'L TAXPAYER ADVOC. BLOG (Sept. 13, 2018), https://taxpayeradvocate.irs.gov/news/nta-blog-the-irs-might-recover-eitc-usingits-newly-discovered-post-processing-math-error-authority-but-is-it-constitutional (questioning whether IRS procedures violate due process norms); National Taxpayer Advocate Nina Olson Comments on Passport Revocation Copy, NAT'L SOC'Y OF TAX PROFS. BLOG (Jan. 23, 2019), https://nstp.org/blog/ national-taxpayer-advocate-nina-olson-comments-on-passport-revocation-copy/ (questioning whether IRS procedures violate due process norms as well).
}

Pitt Tax Review | ISSN 1932-1821 (print) 1932-1996 (online) DOI 10.5195/taxreview.2020.117 | http://taxreview.law.pitt.edu 
roadmap for future advocates who will continue exploring ways to improve the experiences of the people whose lives are entwined with the IRS.

Nina's insights and concerns will continue to influence many. I suspect that the influence will one day extend to courts considering the constitutional sufficiency of how the IRS interacts with taxpayers. As Parkin notes, procedural innovations should inform courts as they perform the balancing associated with modern due process jurisprudence. Context matters. Even beginning the conversation about balancing the interests of taxpayers advances the ball in tax administration. There has been no one more associated with highlighting taxpayers' interests than Nina. Through her work Nina has helped clarify that taxpayers, and the impact that the IRS has on their lives, should always be a fundamental aspect of tax administration. For that, we admire the work she has done and will continue to do, and we look forward to its continued impact. 
